Тарималжуулсан хоёр зүйл Хунчирын эмийн түҮхий эдийн стандартчиллын асуудлууд

\author{
Г. Одонтуяа ${ }^{1 *}$, Р. Одням ${ }^{1}$, М. Номин ${ }^{1}$, Ц. Номуун ${ }^{1}$, Л. Энхбат ${ }^{2}$, Н. Ундрах ${ }^{3}$
}

${ }^{1}$ Хими, химийн технологийн хүрээлэн, Шинжлэх ухааны академи, Улаанбаатар 13330, Монгол улс.

${ }^{2}$ Астра РҮҮт ХХК, Дэлгэрхаан сум, Хэнтий аймаг, Монгол Улс. ${ }^{3}$ Премиут групп ХХК, Улаанбаатар 14241, Монгол Улс.

*E-mail: odontuyag@mas.ac.mn

\begin{tabular}{|c|c|c|}
\hline Хүлээн авсан: 30.04 .2020 & & Хэвлэлтэнд авсан: 11.09.2020 \\
\hline
\end{tabular}

\begin{abstract}
Хураангуй: Эмийн ургамлыг тарималжуулан хэрэглэх нь үйлдвэрлэлийг стандартын шаардлага хангасан түүхий эдээр тасралтгүй ханган нийлүүлж явуулах нэг арга болохын зэрэгцээ тухайн зүйл ургамлыг хамгаалах ач холбогдолтой. Манай орны Хэнтий аймгийн Хэрлэнбаян-Улаанд тарималжуулсан Сарьслаг хунчир, Монгол хунчирын үндэс түүхий эдийн чанарын тоон үзүүлэлтүүдийг Монгол Улсын Үндэсний Фармакопейнд бичигдсэн арга зүйн дагуу, биологийн идэвхт үйлчлэгч гол нэгдэл сапонины тоо хэмжээг спектрофотометрийн аргаaр тодорхойлж, тэдгээрийн зөвшөөрөгдөх хязгаарыг тогтоов. Туршилт судалгааны дүнд хоёр зүйл хунчирын үндэсний чийг $10.0 \%$, нийт үнс Сарьслаг хунчирынх $2.38 \pm 0.05 \%$, Монгол хунчирынх $4.18 \pm 0.86 \%$, сулруулсан НCI-д үл уусах үнс $0.16 \pm 0.04 \%$ ба $0.28 \pm 0.07 \%$ гэж зөвшөөрөгдөх хязгаарт, нэрсэн усанд хандлагдах бодисын хэмжээ $26.83 \pm 0.30 \%$ ба $37.51 \pm 1.62 \%$ байгааг тодорхойлов. Биологийн идэвхт үйлчлэгч нэгдэл сапонин нь Сарьслаг хунчирын үндсэнд $0.044 \pm 0.009 \%$, Монгол хунчирынхад $0.028 \pm 0.006 \%$ тус тус агуулагдаж байна. Эндээс Монгол хунчирын үндсэнд усанд уусдаг бодисууд, ялангуяа полисахар их хэмжээтэй, харин Сарьслаг хунчирын үндсэнд сапонин гликозид илүү агуулагдаж байгааг тогтоов.
\end{abstract}

Түлхүүр үг: Сарьслаг хунчир, Монгол хунчир, фармакогнозын чанарын Үзүүлэлт, нийт сапонин

\section{ОРШИЛ}

Хунчир (AstragalusL.) бол Буурцагтны (Fabaceae) овгийн ургамал бөгөөд түүнийг Huang-qi (хятадаaр) “шар удирдагч” гэж нэрлэн өнө эртнээс Хятадын уламжлалт анагаах ухаанд олон мянган жилийн турш дасан зохицуулах үйлдэлтэй гэж хэрэглэж ирсэн бөгөөд энэ нь мэдрэлийн иочролыг дарангуйлж, аливаа өвчний анагаахад тустай гэсэн утгатай юм [1]. Монголчууд хунчирын хатаасан үндсийг махтай чанаж иддэг байсан ба хүмүүс аян замд явахдаа нөөцлөн авч хүнсэндээ хэрэглэн ядаргаагаа тайлах болон өвчин эсэргүүцэх чадвараа сайжруулан дархлаагаа дэмжих, цус алдах, шарх эдгээхэд хэрэглэдэг байв [2]. Монгол хунчирын (Astragalus mongolicus Bge) үндсийг монгол, нангиад эмнэлэгт архаг өвчний улмаас буюу насны эрхээр бие доройтож тамирдах, ядрах, зүрхний үйл ажиллагаа сулрах, дутагдах, цус алдах үед хэрэглэдэг. Үндэсний чанамлыг биеийн ерөнхий байдлыг сайжруулж, тордон тэнхрүүлэх, хөлрөлтийг дарах, шимжүүлэх, цус тогтоох, шарх эдгээх, идээт шар усыг татахад тустай гэж хэрэглэдэг. Сарьслаг хунчирын (Astragalus membranaceus (Fisch.) Bge) үндсийг монгол, нангиад, солонгос эмнэлэгт цусны даралт ихсэх, чихрийн шижин, бөөрний үрэвсэл, хэвлийн хаван, ходоод гэдэсний өвчин, арьсны идээт үрэвсэл, бэлгийн сулрал, эмэгтэйчүүдийн өвчнийг анагаахад хэрэглэдэг уламжлалтай [3]. Хунчир нь дорно дахины анагаaх ухаанд хэрэглэдэг эмийн 330 жоронд орж, давтамжаараа 10-рт байдаг ба Монгол-Төвөд эмийн жоронд орох давтамжаараа эхний 90-д ордог. Нангиад эмнэлэгт түүнийг тамиржуулан залуужуулдаг гэж чухалчлан заасан байдаг бөгөөд эмийн 12 чухал жорын найрлаганд ордог [4].

Манай дэлхийд Хунчирын 2000-3000 гаруй зүйл ургадаг ба ялангуяа Хятадын зүүн ба хойд бүс нутаг, мөн Монгол, Хойд Солонгос, ОХУ-Сибирьт бага хэмжээгээр, хуурай, сэрүүн бүсэд тархан ургадаг [5,6]. Монголд хунчирын 70 зүйл ургадаг гэж бүртгэгдсэн ба эдгээрээс 21 зүйл нь зөвхөн манай оронд ургадаг эндемик ургамал юм $[7,8]$.

Хунчир нь нэг болон олон наст өвслөг ургамал ба мөн зарим газар сөөг, бут ургамал юм. 1970-аад оны үеэс хунчирын химийн бүрэлдэхүүний судалгааг хийж эхлэн одоогоор 100-аад зүйл ургамлын химийн судалгаа тодорхой хэмжээгээр хийгдсэний дүнд хүний эрүүл мэндэд ашиг тустай сапонин, флавоноид, полисахар гэсэн 3 анги бүлгийн нэгдлүүд, мөн зарим зүйлд хортой шинж чанартай 3 бүлэг нэгдэл агуулагддаг болохыг тогтоожээ $[9,10,11]$. Хортой шинж чанартай хунчирын зүйлүүд Хойд Америкт ургадаг ба эдгээрт индолизидиний алкалоид, алифатик нитро нэгдэл, селений (Se) метаболитууд агуулагдаж, ихэвчлэн мал, зэрлэг амьтдыг хордуулдаг $[9,10]$. Өнөөг хүртэл хунчирын зүйл ургамлуудаас 520 гаруй терпеноид буюу сапонин, флавоноид зонхилон, 
мөн бусад ангиллын нэгдлүүд ялгагдаж бүтэц байгууламж нь тогтоогджээ [9-12]. Эдгээр нэгдлээс 360 терпеноид, Үүнээс циклоартаны сапонин 292, олеаноны сапонин 50, 152 флавоноид, үүнээс флавонол 61, изофлавоноид 53, флавон 22 тус тус зонхилон агуулагддаг. Сарьслаг хунчир, Монгол хунчирын үндэснээс полисахарыг ялгаж бүтэц байгууламжийг нь тогтоожээ [13-16].

Хунчирын зүйл ургамлуудын үрэвслийг дарах, дархлааг дэмжих, үл исэлдүүлэх (антиоксидант), хорт хавдрыг эмчлэх, зүрх судасны үйл ажиллагааг хамгаалах, дэмжих, элэг хамгаалах, вирусын идэвхийг дарангуйлах болон устгах, чихрийн шижинг эмчлэх үйлдлийг судалж тодорхойлжээ. Ялангуяа хунчираас ялгасан полисахар ба сапонин нь in vitro ба in vivo нөхцөлд үрэвслийг дарах, шарх анагаах, арьсны үрэвсэлт шархны эдгэрэлтийг түргэсгэдэг [17,18], полисахар, сапонин нь эсрэг биетийн тоог олшруулж дархлаа дэмжих улмаар вирусыг дарангуйлах идэвхтэй [13,19,20], полисахар, сапонин, флавоноид нь хорт хавдрын эсрэг идэвхтэй [21-23], флавоноидууд антиоксидант идэвхтэй, эдийн бүтцийг хамгаалан судасны хананд товруу үүсэх, зүрхний шигдээс үүсгэх хүчин зүйлсийн идэвхийг бууруулдаг [24,25], полисахар нь инсулины дохиоллыг зохицуулж 2-р хэлбэрийн чихрийн шижингийн эмчилгээг дэмждэг, мөн астрагалозид IV сапонин нь чихрийн шижингийн үед захын мэдрэлийн өвчлөлийг бууруулах идэвхтэй болохыг тогтоожээ [26,27].

Хунчирын олон зүйл ургамлаас Сарьслаг хунчир, Монгол хунчирын үндсийг уламжлалт болон орчин үеийн анагаах ухаанд өргөн хэрэглэдэг ба үндэс түүхий эдийг байгальд ургаж байгаа ургамлаас бэлтгэхээс гадна тарималжуулан бэлтгэж байгаа нь эмийн үйлдвэрлэлийг тасралтгүй явуулахад нэн чухал юм. Орчин үед эмийн зах зээлд ургамлын гаралтай эм бэлдмэл, бүтээгдэхүүний нэр төрөл олширч, хэрэглээ өсөж байгаа бөгөөд үүнтэй уялдан эмийн ургамлын түүхий эдэд тавигдах шаардлагын үзүүлэлт нэмэгдэж, аюулгүйн үзүүлэлтүүдийн зөвшөөрөгдөх хязгаар өөрчлөгдөж байна. Иймд эмийн ургамлын түүхий эдийн хуучин стандартыг шинэчлэх, мөн шинээр стандартчилах шаардлага зайлшгүй болж байна.

Бид энэхүү өгүүлэлд Хэнтий аймгийн ХэрлэнбаянУлаанд тарьж ургуулсан Сарьслаг хунчир ба Монгол хунчир ургамлын эмийн түүхий эд болох үндэсний Монголын Үндэсний Фармакопейн өгүүлэл боловсруулах зорилгоор хийсэн туршилт, судалгааны үр дүнг боловсруулан, дүн шинжилгээ хийсэн болно.

\section{СУДАЛГААНЫ МАТЕРИАЛ, АРГА ЗУЙ}

Ургамлын түухий эдийг судалгаанд бэлтгэх: Монгол хунчир ургамлын үндсийг 2018 оны 8-р сарын сүүл, Сарьслаг хунчир ургамлын үндсийг 2017 оны 9 -p сард Хэнтийн Хэрлэнбаян-Улаанд Астра РүҮт ХХК-ий үрээр тарималжуулсан талбайгаас ургалтын 4 дэх жилд тус тус түүж бэлтгэв. Түүж бэлтгэсэн үндсийг нарны шууд тусгалаас хамгаалсан, салхи нэвтрэх тавиур бүхий байранд нимгэн үеэр дэлгэж хатаав.

Үндэсний чанарын тоон ҮзУҮлэлтийн тоо хэмжюэг тодорхойлох: Үндэсний чийг, нийт үнс, сулруулсан хлорт устөрөгчийн хүчил (НCI)-д үл уусах үнс, нэрсэн усанд хандлагдах бодисын тоо хэмжээг Монгол Улсын Үндэсний Фармакопей (МУҮФ) дахь арга зүйн дагуу тус тус тодорхойлов [28-30].

Сапониныг таних өнгөт урвал: Нунтагласан үндэс тус бүрээс 1 г-ыг жинлэн авч 25 мл-ийн зүлгэмэл амсартай нэрлэгийн колбонд хийнэ. Дээр нь тус бүр 10 мл 80\%-ийн этилийн спирт (EtOH) нэмж, эргэх хөргөгчтэй холбон усан халаагуурт 10 минут буцалгаад хөргөнө. Астрагалозид IV бодисоос 1 мгыг жинлэн жижиг шилэн саванд авах ба дээр нь 0.5 мл метилийн спирт $(\mathrm{MeOH})$ нэмж уусгана.

Бэлтгэсэн ханд болон стандарт бодис астрагалозид IV-ийн уусмалаас шилэн гуурсаар силикагель $\mathrm{F}_{254}$ ялтас дээр тус тус дусааж, хлороформ:метанол:ус70:30:4 уусгагчийн системд хроматограф явуулна. Хроматограмыг 1\%-ийн ванилин ба 5\%-ийн $\mathrm{H}_{2} \mathrm{SO}_{4}$ ийн оношлуур урвалжаар дараалуулан үйлчилж $100^{\circ}$ $-105^{\circ} \mathrm{C}$-д халаахад тритерпений сапонины төрлийн бодисууд үзэгдэх гэрэлд нил ягаан өнгө үзүүлнэ. Астрагалозид IV зонхилох бодисын $\mathrm{R}_{\mathrm{f}}=0.35$ байна [31].

Нийт тритерпений сапонины уламжслалын нэгдлийн тоо хэмжсээ тодорхойлох: Хунчирын үндсэнд нийт сапонины тоо хэмжээг Хятадын судлаач Tang Jun-ы боловсруулсан колориметрийн аргын арга зүйд бага зэрэг өөрчлөлт хийж тодорхойлов [32]. Үндэсний 1г (2 мм-ийн шигшүүрээр шигшсэн) дээжийг нарийвчлалтай жинлэн 250 мл-ийн бөөрөнхий ёроолтой колбонд хийж, дээр нь 100 мл хлороформ нэмж эргэх хөргөгчтэй холбон усан халаагуурын температурыг $60^{\circ} \mathrm{C}$-д тохируулан 2 цаг хандалж туйлгүй бодисуудыг хлороформоор хандалж зайлуулна. Ургамлын дээжийн үлдсэн шааран дээр 50 мл бутанол хийж $30^{\circ} \mathrm{C}$ хэмд 1 цагийн турш 45 кГц-ийн хэт авианы баннад хандалж, дараа нь тасалгааны температурт хонуулна.

Дээжийг дээрх нөхцөлд дахин 1 цаг хэт авианы баннад хандалсны дараа цаасан шүүлтүүрээр шүүгээд, шүүгдсийг вакуум ууршуулагчаар нэрж уусгагчийг бүрэн зайлуулна. Үүний дараа гарган авсан бутанолын хандыг 5-7 мл нэрсэн усанд уусгаад D101 макропор шингээгч дундуур нэвтрүүлж бусад дагалдах бодисоос цэвэрлэнэ. 
Үүний тулд 5-6 г D101 шингээгчийг цэвэр этанолд уусган 1.5 х 30 см шилэн баганад суулгаж, тус бүр 50 мл этанол, ус, 10\%-ийн хлорт устөрөгчийн хүчил, 10\%-ийн натрийн шүлтийн уусмалаар дараалуулан угаан цэвэрлэж, усаар сайтар угаасны дараа 96\%-ийн ЕtOH-д 12 цаг байлгана. Дараа нь шингээгчийн этанолыг зайлуулж, нэрсэн усаар сайтар угаасны дараа нэрсэн усанд уусгасан дээжийг суулгаж, эхлээд 50 мл нэрсэн усаар угааж хаяна. Үүний дараа шингээгчтэй баганыг 50-60 мл 70\%-ийн этанолоор угааж шилэн аяганд тосож авах ба энд сапонин хөөгдөж гарч ирнэ.

Энэхүу 70\%-ийн этанолон хандыг вакуум ууршуулагчаар сайтар нэрж уусгагчийг зайлуулах ба нэрлэгийн колбыг 20-30 минут тасалгааны температурт байлгаж жинг тогтворжуулсны дараа жинлэж, нийт бодисын хэмжээг граммд шилжүүлнэ. Нэрлэгийн колбо дахь бодисыг бага хэмжээний цэвэр метанолд уусгаад 10 мл-ийн хэмжээст колбо руу шилжүүлэх ба колбыг дахин 2-3 удаа бага хэмжээний метанолоор угааж хэмжээст колбо руу нийлүүлж, хэмжээс хүртэл метанол нэмж дээж уусмалыг бэлтгэнэ.

Бэлтгэсэн дээж уусмалаас 1 мл-ийг хуруу шилэнд авч дээр нь 0.5 мл 8\%-ийн ванилин, 2.5 мл 72\%-ийн $\mathrm{H}_{2} \mathrm{SO}_{4}$ нэмж $70^{\circ} \mathrm{C}$ бүхий усан халаагуурт 15 мин. халааж урвалыг явуулна. Үүний дараа хуруу шилтэй уусмалыг урсгал хүйтэн усаар хөргөж, 5-10 минутын дараа гэрэл шингээлтийг спектрофотометрээр 560 нм-ийн утганд харьцуулах уусмалтай харьцуулан хэмжинэ. Харьцуулах уусмал болгон хуруу шилэнд 1 мл дээж уусмал, 2.5 мл 72\%ийн $\mathrm{H}_{2} \mathrm{SO}_{4}, 0.5$ мл МеОН авч хольж бэлтгэнэ.

Yр дүнг тооцоолох: Стандарт бодисын уусмалын жиших муруйг ашиглан шинжилж буй 1 г дээжинд агуулагдах нийт сапонины тоо хэмжээг олж гаргах ба дараахь томъёог ашиглан 100 г үнэмлэхүй хуурай дээжинд шилжүүлэн бодно. Үүний дүнд шинжилж буй дээжинд агуулагдах нийт сапонины тоо хэмжээ астрагалозид IV-T шилжүүлснээр хувиар илэрхийлэгдэнэ.

Стандарт бодисын уусмал бэлтгэх: Стандарт бодис астрагалозид-IV-өөс 5мг-ыг нарийвчлалтай жинлэн жижиг шилэн аяганд авч, бага хэмжээний цэвэр МеОН-д уусгаад 10 мл-ийн хэмжээст колбонд

$$
\mathrm{x}(\%)=\frac{a x 100}{m} \times \frac{100}{(100-w)}
$$

$\mathrm{X}$ - нийт сапонины тоо хэмжээ астрагалозид IV-T шилжүүлснээр, \%

m - шинжилгээнд авсан дээжийн масс, г

$\mathrm{a}-$ жиших муруй ашиглан олсон дээж дэх нийт сапонин, г

w - дээжийн чийг, \% шилжүүлнэ. Шилэн аягыг бага хэмжээний $\mathrm{MeOH}-$ оор 2 удаа зайлж хэмжээст колбо руу хийх ба хэмжээс хүртэл МеОН нэмнэ (А уусмал).

Бэлтгэсэн А уусмалаас тус бүр $0.125,0.25,0.375,0.5$, $0.625,0.75,0.875,1.0$ мл-ийг хуруу шилэнд авч, $70^{\circ} \mathrm{C}$ -д халаасан усан халаагуурт тавьж уусгагчийг ууршуулна. Дараа нь хуруу шил тус бүрт 0.5 мл 8\%ийн ванилин, 2.5 мл 72\%-ийн $\mathrm{H}_{2} \mathrm{SO}_{4}, 1$ мл $\mathrm{MeOH}$ нэмж $70^{\circ} \mathrm{C}$ бүхий усан халаагуурт 15 мин. халааж урвалыг явуулна. Үүний дараа хуруу шилтэй уусмалуудыг урсгал хүйтэн усаар хөргөж, 5-10 минутын дараа гэрэл шингээлтийг спектрофотометрийн 560 нм-ийн утганд харьцуулах уусмалтай харьцуулан хэмжинэ.

Харьцуулах уусмал бэлтгэх: Стандарт бодисоос бэлтгэсэн А уусмалаас тус бүр $0.125,0.25,0.375,0.5$, $0.625,0.75,0.875,1.0$ мл-ийг хуруу шилэнд авч, $70^{\circ} \mathrm{C}$ -д халаасан усан халаагуурт тавьж уусгагчийг ууршуулна. Хуруу шил тус бүрт 2.5 мл 72\%-ийн $\mathrm{H}_{2} \mathrm{SO}_{4}, 1.5$ мл МеОН нэмж стандарт бодисын харгалзах уусмал тус бүртэй харьцуулан хэмжинэ.

Жиших муруй байгуулах: Стандарт бодисын уусмал тус бүрийн 560 нм дэх гэрэл шингээлтийн утга ба харгалзах уусмалын ууссан бодис бүрийн массын хамаарлаар жиших муруйг excel програм ашиглан байгуулна.

Пестицид тодорхойлох: Үндэс түүхий эдийг жижиглэж, 2 мм-ийн шигшүүрээр шигших ба үүнээс 10 г-ыг нарийвчлалтай жинлэн авч 250 мл-ийн шувтан колбонд хийнэ. Дээр нь 200 мл ацетон: дихлорметан -1:1 уусгагч, 5 г натрийн хлорид $(\mathrm{NaCl})$ хийж 5 минутын турш соронзон хутгагч дээр хутган хандална. Дараа нь ханд уусмалыг шүүлтийн цаасаар шувтан колбо руу шүүх ба шүүгдсийг 5 г усгүй натрийн сульфат $\left(\mathrm{Na}_{2} \mathrm{SO}_{4}\right)$ дундуур нэвтрүүлж усыг нь зайлуулна. Шүүгдэс-хандыг вакуум ууршуулагчаар 2 мл болтол нэрж багасгана. Хандыг урьдчилан 6 мл гексан:петролейний эфир - 1:1 уусгагчаар угаасан C18-SPE (chromabond ${ }^{\circledR}$ C18) шингээгчтэй багана дундуур вакуум насос ашиглан нэвтрүүлэх ба дараа нь баганыг 6 мл гексан:петролейний эфир - 1:1 уусгагчаар угааж, элюатыг тосож авна [33]. Элюатыг вакуум ууршуулагчаар нэрж хуурайшуулан дихлорметанд уусгаж хийн хроматограф-масс спектрометрийн (XX -MC, GC, Thermo Scientific (Trace 1310)-MS, TSQ 8000) аргаар шинжилнэ.

$\boldsymbol{X X - M C - и и ̆ н ~ ш и н ж е л л г э : ~ X X - M C - и и ̆ н ~ б а г а н ы н ~ ( D B - ~}$ $5 \mathrm{MS})$ урт 30 м, дотоод голч 0.25 мм, 0.25 мкм хальс бүхий капилляр юм.

Багажийн эхний температурыг $60^{\circ} \mathrm{C}$-д 1 минутын турш барьж, дараа нь $200^{\circ} \mathrm{C}$ хүртэл $30^{\circ} \mathrm{C}, 300^{\circ} \mathrm{C}$ хүртэл $10^{\circ} \mathrm{C} /$ мин ихсэхээр программчилж температурыг $300^{\circ} \mathrm{C}$-д 5 минутын турш барихаар 
тохируулна. Дээж ачаалах хэсгийн температур $250^{\circ} \mathrm{C}$ байхад 1 мкл эзэлхүүнтэй дээжийг тарьж, гели зөөгч хийн урсгалын хурд 1.5 мл/мин, даралтыг 9.10 пси (psi) байлгана. Масс спектрометрийг электрон ионжуулалтын горим дээр тохируулж, ионы үүсвэрийн температур $300^{\circ} \mathrm{C}$ байна.

\section{ҮР ДҮН, ХЭЛЭЛЦУУЛЭГ}

Манай оронд ургадаг Хувьсанги хунчир (Astragalus variabilis Bge. ex Maxim.)-ын өвс, Нумраа хунчир (Astragalus adsurgens Pall.)-ын өвс, Дайралдмал хунчир (Astragalus inopinatus Boriss.)-ын өвс, Цагаалин хунчир (Astragalus galactities Pall.)-ын өвс, Монгол хунчир (Astragalus mongolicus Bge)-ын үндэс түүхий эдийн стандарт боловсруулагдаж Монгол Улсын Үндэсний Фармакопейд орсон байдаг [28]. Сүүлд Уламжлалт Анагаах Ухаан Технологийн Эрдэм Шинжилгээний Хүрээлэн ба ШУА-ийн Ерөнхий ба Сорилын Биологийн Хүрээлэн хамтран Цагаалин хунчирын өвсний фармакопейн өгүүлэлд зарим өөрчлөлт хийж дахин боловсруулан баталгаажуулжээ [34]. Ингэхдээ тритерпений нэгдлийн чанарын шинжилгээг нимгэн үеийн хроматографын аргаар хийж, сулруулсан НCI-д үл уусах үнсийг шинээр тодорхойлж, нийт фенолт нэгдлийг Фолин-Чикольтегийн урвалж ашиглан тодорхойлсон ба түүхий эдийн аюулгүйн үзүүлэлт болох бичил биетний бохирдлыг тодорхойлсон байна.

Бид Хэнтий аймгийн Хэрлэнбаян-Улаанд тарималжуулсан Сарьслаг хунчир ба Монгол хунчир ургамлуудын үндэс түүхий эдийг ургалтын 4 дэх жилд бэлтгэн фармакогнозын тоон үзүүлэлт, чанар, тооны шинжилгээг анх удаа хийж фармакопейн өгүүллийн төслийг боловсрууллаа. Түүхий эдийн чанарыг гадна байдал, өнгө, үнэр, органик хольцын тоо хэмжээгээр тодорхойлсноос гадна чийг, нийт үнс, сулруулсан НСІ-д үл уусах үнс, нэрсэн усанд хандлагдах бодисуудын тоо хэмжээг тус тус тодорхойлж үр дүнг Хүснэгт 1-д харуулав.

Сарьслаг хунчир, Монгол хунчирын үндэс нь голлосон ба олон салаалсан. Нунтагласан үндэс цайвар шаргал өнгөтэй, утаслаг ширхэгүүдтэй, ялгарах гойд үнэргүй, бага зэрэг чихэрлэг амттай. Хоёр зүйл хунчирын үндэс нь морфологийн шинжээр онцын ялгаа байхгүй.

Туршилт судалгааны үр дүнд хоёр зүйл хунчирын эмийн түүхий эдийн чийг, нийт үнс, сулруулсан НCI -д үл уусах үнсний хэмжээ зөвшөөрөгдөх хязгаарт байв. Ургамлын түүхий эдээс хамаарч түүнийг агаарын хуурай болтол хатаасны дараа чийг 10-14 \%, зарим шүүслэг үр жимс 16-20 \% чийгтэй [35], нийт үнс 3-25 \%-ийн хязгаарт байдаг бол харин хүчилд үл уусдаг үнс 2 \%-иас ихгүй байдаг [36]. Хунчирын зүйл ургамлуудын биологийн идэвхт бодисууд бол полисахар, сапонин гликозид бөгөөд эдгээр нь усанд сайн уусдаг. Монгол хунчирын үндэснээс усанд хандлагдах бодисын тоо хэмжээ Сарьслаг хунчирынхаас их байгаа нь түүнд дээрх бодисууд илүү агуулагдаж байх магадлалтайг илэрхийлж байгаа ба ялангуяа полисахар их байж болох юм. Ургамлын эмийн түүхий эдийн дээрх фармакогнозын чанарын тоон үзүүлэлтүүд нь Дэлхийн Эрүүл Мэндийн Байгууллагаас (ДЭМБ) эрхлэн гаргасан "WHO Monograph on selected Medicinal Plants, Vol-1” [37] болон Хятадын фармакопей дахь Хунчирын үндэс өгүүлэл [30] дэх нэрсэн усанд хандлагдсан бодисуудын тоо хэмжээ $17 \%$-иас багагүй, нийт үнс 5-6 \%-иас ихгүй, сулруулсан хүчилд үл уусдаг үнс 1 \%-иас ихгүй гэсэн үзүүлэлтийн хязгаарт тохирч байна. Хоёр зүйл хунчир ба стандарт бодис астрагалозид IV-ийн чанарын шинжилгээг нимгэн үеийн хроматографын аргаар туйлтай уусгагчийн системд явуулж, ванилин, хүхрийн хүчил оношлуур урвалжуудаар үйлчилж халаахад (арга зүйг үз) сапонины гликозидууд үзэгдэх гэрэлд нил ягаан өнгөтэй ба астрагалозид IV-ийн $\mathrm{R}_{\mathrm{f}}=0.35$ бол флавоноидыг илрүүлэх “байгалийн нэгдэл” урвалжаар үйлчлэхэд тодорхой толбо илрэхгүй байв. Тэгэхээр үндсэнд мэдэгдэхүйц хэмжээний флавоноид байхгүй байна.

Манай улсад Хувьсанги хунчирын өвс, Нумраа хунчирын өвс, Дайралдмал хунчирын өвс түүхий эдэд нийт флавоноид, Цагаалин хунчирын өвсөнд нийт полифенолт нэгдэл, Монгол хунчирын үндсэнд нийт флавоноидын тоо хэмжээг тодорхойлон стандартчилж баталгаажуулсан байна [28,34]. Монгол хунчирын үндсэнд нийт сапонины тоо хэмжээг Европын фармакопейд өндөр мэдрэмжит шингэний хроматографын (ӨМШХ) арга [38], Хятадын фармакопейд нимгэн үеийн сканнин аргаар [30] тус тус тодорхойлсон байдаг.

Мөн астрагалозидыг ванилин, хүхрийн хүчил эсвэл анисийн хүчилтэй урвалд оруулж спектрофлюорометрийн аргаар тодорхойлсон байдаг $[39,40]$. Эдгээр арга нь мэдрэх чадвар сайтай,

ХУснэгт 1. Тарималжуулсан Сарьслаг хунчир ба Монгол хунчир ургамлуудын үндэс-түҮхий эдийн фармакогнозын чанарын тоон ҮзҮҮлэлт

\begin{tabular}{cccccc}
\hline \multirow{2}{*}{$№$} & Ургамлын нэр & Чийг, \% & Нийт үнс, \% & $\begin{array}{c}\text { Сулр. НС-т } \\
\text { уусдаггүй үнс, \% }\end{array}$ & $\begin{array}{c}\text { Усанд хандлагдах } \\
\text { бодис, \% }\end{array}$ \\
\hline 1 & Сарьслаг хунчир & $10.08 \pm 0.04$ & $2.38 \pm 0.05$ & $0.16 \pm 0.04$ & $26.83 \pm 0.30$ \\
2 & Монгол хунчир & $9.78 \pm 0.18$ & $4.18 \pm 0.86$ & $0.28 \pm 0.07$ & $37.51 \pm 1.62$ \\
\hline
\end{tabular}


хялбар, хурдан, бага хэмжээтэй бодисыг тодорхойлох чадвартай зэрэг давуу талтай. Бид тарималжуулсан Сарьслаг хунчир ба Монгол хунчирын үндсэнд нийт сапонины тоо хэмжээг Хятадын судлаач Tang Jun-ы боловсруулсан спектрофотометрийн аргаар астрагалозид IV-T шилжүүлж тодорхойлов [32] (Хүснэгт 2).

Ингэхдээ арга зүйг бага зэрэг өөрчилж, эхлээд үндэсний дээжийг хлороформоор усан халаагуурт

ХУснэгт 2. Тарималжуулсан Сарьслаг хунчир ба Монгол хунчир ургамлуудын үндсэн дэх сапонины тоо хэмжээ

\begin{tabular}{cccc}
\hline № & $\begin{array}{c}\text { Ургамлын } \\
\text { нэр }\end{array}$ & $\begin{array}{c}\text { Шинжилгээний } \\
\text { арга }\end{array}$ & $\begin{array}{c}\text { Сапонины тоо } \\
\text { хэмжээ, \% }\end{array}$ \\
\hline 1 & $\begin{array}{c}\text { Сарьслаг } \\
\text { хунчир }\end{array}$ & $\begin{array}{c}\text { Спектрофото- } \\
\text { метрийн арга }\end{array}$ & $0.044 \pm 0.009$ \\
2 & $\begin{array}{c}\text { Монгол } \\
\text { хнччир }\end{array}$ & $0.028 \pm 0.006$ \\
\hline
\end{tabular}

эргэх хөргөгчтэй холбон 2 цаг хандалсны дараа үлдсэн дээжийг $н$-бутанолоор $30^{\circ} \mathrm{C}$ хэмд, 45 кГц давтамжтай хэт авианы баннад тус бүр 1 цагаар 2 удаа, дундаа тасалгааны хэмд 12 цаг тавьж эрчимжүүлэн хандлав. Үүний дүнд дээж туйлгүй бодисуудаас цэвэрлэгдэж, сапонины гликозидийн гарц нэмэгдсэн юм (ХУснэгт 2).

Туршилт судалгааны дүнд Сарьслаг хунчирын үндсэнд биологийн идэвхт үйлчлэгч бодис сапонин нь Монгол хунчирынхаас илүү их агуулагдаж буйг тогтоов. ӨМШХ ба нимгэн үеийн сканнин аргаар Монгол хунчирын үндсэнд нийт сапониныг астрагалозид IV-т шилжүүлэн 0.040 \%-иас багагүй гэсэн үр дүнтэй харьцуулахад бидний спектрофотометрийн аргаар тодорхойлсон үр дүн бага байна. Гэхдээ спектрофотометрийн арга нь харьцангуй нарийвчлал сайтай, тогтвортой, тохирцтой, ажиллагаа нь энгийн, хялбар, хүртээмжтэй юм. Тарималжуулсан Монгол хунчир, Сарьслаг хунчир ургамлуудын үндэсний дээжинд $\mathrm{XX-MC-ийн} \mathrm{аргаар} \mathrm{пестицидийн} \mathrm{үлдэгдлийг}$ тодорхойлов (Зураг 1 ба 2).

Шинжилгээний дүнд тарималжуулсан хоёр зүйл хунчирын эмийн түүхий эд болох үндэсний хандны

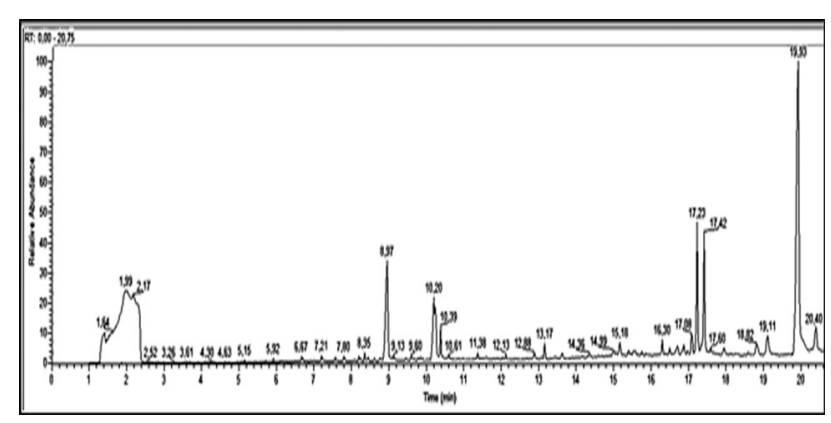

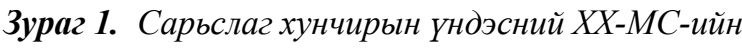
хроматограм

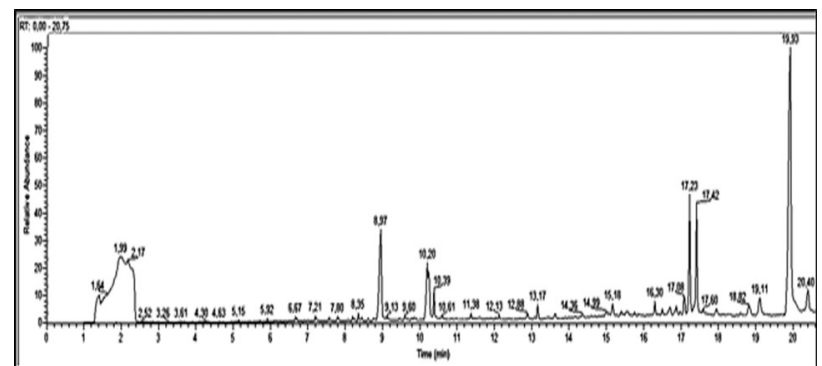

Зураг 2. Монгол хунчирын үндэсний $X X-M C$-ийн хроматограм

хроматограм ерөнхийдөө ижил байгаа бөгөөд пик тус бүрийг өгөгдлийн сангаас хайж, нягтлахад пестицидийн ангиллын нэгдлүүд илрээгүй. Мөн ДЭМБ-с гаргасан монографад [37] бичигдсэнээр хунчирын үндсэнд алдрин ба деилдриний пестицидийн үлдэгдлийн дээд хэмжээ 0.05 мг/кг-аaс ихгүй гэсэн заалттай ба манай оронд тарималжуулсан Сарьслаг хунчир, Монгол хунчир ургамлын үндсэнд эдгээр пестицид илрээгүй.

Бид туршилт судалгааны үр дүнгээ МХЕГ-ын ХАБҮЛЛ-ийн шинжилгээгээр баталгаажуулсан болно.

\section{ДУГНЭЛТ}

Тарималжуулсан Сарьслаг хунчир, Монгол хунчирын эмийн түүхий эд болох үндэсний ялган оношлогоог тэдгээрийн гадна байдал, өнгө, үнэр, органик хольцын тоо хэмжээгээр тодорхойлсноос гадна чийг, нийт үнс, сулруулсан хлортустөрөгчийн хүчилд үл уусах үнс, усанд хандлагдах бодисын тоо хэмжээг тодорхойлов. Түүхй эдийн фармакогнозын чанарын эдгээр тоон үзүүлэлт нь эмийн ургамлын эмийн түүхий эдэд тавигдах шаардлага, зөвшөөрөгдөх хязгаарт тохирч байгаа ба тарималжуулсан 2 зүйл хунчирын үндэсний дээрх үзүүлэлтүүдийг тогтоов. Биологийн идэвхт үйлчлэгч нэгдэл сапонин нь Сарьслаг хунчирын үндсэнд $\quad 0.044 \pm 0.009 \%, \quad$ Монгол хунчирынхад $0.028 \pm 0.006 \%$ тус тус агуулагдаж байгааг тогтоосноор энэ 2 ургамлын үндэс түүхий эдийн Монголын Үндэсний Фармакопейн өгүүлэл боловсруулах нөхцөл бүрдэж, улмаар тэдгээрийг үйлдвэрлэлд түүхий эд болгон ашиглах боломжтой болов. Чанартай түүхий эдээс чанартай бүтээгдэхүүн гарна.

\section{ТАЛАРХАЛ}

Тооны шинжилгээний хэмжилтийг UV2550 (Shimadzu, Япон) спектрофотометр багажаар хийж тусалсан ШУА-ийн Физик Технологийн Хүрээлэнгийн Байгаль Шинжлэлийн Лабораторийн эрдэм шинжилгээний ажилтан, инженер Ц.Бямбасүрэнд чин сэтгэлээсээ талархал илэрхийлье. 


\section{АШИГЛАСАН МАТЕРИАЛ}

1. J. Axe. (2018). 10 proven benefits of Astragalus root. https://draxe.com/nutrition/astragalus/.

2. Ц. Хайдав, Б. Алтанчимэг, Т.С. Варламова. (1985). Лекарсвенные растения в Монгольской медицине. Госиздательство, Улаанбаатар. х.5253.

3. У. Лигаa, Б. Даваасүрэн, Н. Нинжил. (2005). Монгол орны эмийн ургамлыг өрнө дорнын анагаах ухаанд хэрэглэхүй. JKC printing, Улаабаатар. х.447-454.

4. Д. Болдсайхан, Х. Нансалмаа, Д. Цэмбэл. (1993). Уламжлалт эмнэлгийн 4000 жоронд эмт бодисын давтамжийг цахим тоолуураар тодорхойлсон дүн. ШУА-ийн Мэдээ, 4, х. 20-29.

5. D. Podlech. The genus Astragalus L. (Fabaceae) in Europe with exclusion of the former Soviet Union. Feddes Repertor, 119, pp. 310-387.

6. L. Xu, D.F. Podlech. (2010). Astragalus Linnaeus, Sp.Pl. 2: 755, 1753. Flora China, 10, pp. 329-333.

7. В.И. Грубов (2008). Монголын гуурст ургамлыг таних бичиг: Astragalus L. - Хунчир. Ган принт, Улаанбаатар, х. 188-197.

8. M. Urgamal, B. Ouyntsetseg, D. Nyambayar, Ch. Dulamsuren. (2014). Conspectus of the vascular plants of Mongolia. Ulaanbaatar, pp. 326.

9. L. Pistelli. (2002). Secondary metabolites of genus Astragalus: Structure and biological activity, Studies Natural Products Chemistry (ed. Atta-urRahman). Elsevier Science, V27, pp. 443-545.

10. Xi. Li, L. Qu, Y. Dong, L. Han, E. Kiu, Sh. Fang, Yi. Zhang, T. Wang. (2014). A review of recent research progress on the Astragalus genus. Molecules, 19, 18850-18880.

11. I.W. Southorn. In phytochemical dictionary of the Leguminosae (eds. Bisby F.A., Buckingham J., Harborne J.B.), Chapman \& Hall, London, 1994, VI, 87-107.

12. Q-T. Yu, L-W. Qi, P. Li, L. Yi, J. Zhao, J-M. Bi. (2007). Determination of main seventeen flavonoids and saponins in the medicinal plants Huang-qi (Radix Astragali) by HPLC-DAD-ELSD. Journal of Separation Science, 30, pp. 1292-1299.

13. M. Tomoda, N. Shimizu, N. Ohara, R. Gonda, S. Ishi, H. Otsuki. (1992). A reticuloendothelial system -activating glycan from the roots of Astragalus membranaceus. Phytochemistry, 31, pp. 63-66.

14. S. Fang, Y. Chen, X. Xu, C. Ye, S. Zhai, M. Shen. (1982). Youj Huoxue, 1, pp. 26-31. CA96:177941.

15. W. Tang, G. Eisenbrand. (1982). Chinese drugs of plant origin. Springer-Verlag, Berlin.

16. Q. Huang, G. Liu, J. Guo. (1981). Yaoxue Tongbao, 16(8), CA96:82697.
17. J.H. Kim, M.H. Kim, G. Yang, Y. Huh, S.H. Kim, W.M. Yang. (2013). Effects of topical application of Astragalus membranaceus on allergic dermatitis. Immunopharmacology and. Immunotoxicology, 35, 151-156.

18. D.Y. Lee, H.J. Noh, J. Choi, K.H. Lee, M.H. Lee, J.H. Lee, Y. Hong, S.H. Lee, S.Y. Kim, G.S. Kim. (2013). Anti-inflammatory cycloartane-type saponins of Astragalus membranaceus. Molecules, 18, pp. 3725-3732.

19. St. Nikolov, N. Benbassat. (1997). Farmasiya (Sofia), 44, pp. 34-48. C.A.130:279228.

20. K. Kajimura, Y. Takagi, K. Miyano, Y. Sawabe, M. Mimura, Y. Sakagami, H. Yokoyama, K. Yoneda. (1997). Polysaccharide of Astragali radix enhances IgM antibody production in aged mice. Biological and Pharmaceutical Bulleten, 20, pp. 1178-1182.

21. Q.E. Tian, H.D. Li, M. Yan, H.L. Cai, Q.Y. Tan, W.Y. Zhang. (2012). Astragalus polysaccharides can regulate cytokine and $P$-glycoprotein expression in $\mathrm{H} 22$ tumor-bearing mice. World Journal of Gastroenterology, 18, pp. 7079-7086.

22. H. Qi, L. Wei, Y. Han, Q. Zhang, A.S. Lau, J. Rong. (2010). Proteomic characterization of the cellular response to chemopreventive triterpenoid astragaloside IV in human hepatocellular carcinoma cell line HEPG2. International Journal of Oncology, 36, pp. 725-735.

23. D. Zhang, Y. Zhuang, J. Pan, H. Wang, H. Li, Y. Yu, D. Wang. (2012). Investigaton of effects and mechanisms of total flavonoids of Astragalus and calycosin on human erythroleukemia cells. Oxidative Medicine and Cellular Longevity, 209843.

24. X. Ma, K. Zhang, H. Li, S. Han, Z. Ma, P. Tu. (2013). Extracts from Astragalus membranaceus limit myocardial cell death and improve cardiac function in a rat model of myocardial ischemia. Journal of Ethnopharmacology, 149, pp. 720-728.

25. D. Wang, Y. Zhuamg, Y. Tian, G.N. Thomas, M. Ying, B. Tomlinson. (2012). Study of the effects of total flavonoids of Astragalus on atherosclerosis formation and potential mechanosms. Oxidative Medicine and Cellular Longevity, doi:org/10.1155/1012/282383.

26. M. Liu, K. Wu, X. Mao, Y. Wu, J. Ouyang. (2009). Astragalus polysaccharide improves insulin sensitivity in KKAy mice: Regulation of $\mathrm{PKB} /$ GLUT4 signaling in skeletal muscle. Journal of Ethnopharmacology, 127, pp. 32-37.

27. J. Yu, Y. Zhang, S. Sun, J. Shem, J. Qiu, X. Yin, H. Yin, S. Jiang. (2006). Inhibitory effects of astragaloside IV on diabetic peripheral neuropathy 
in rats. Canadian Journal of Physiology and Pharmacology, 84, pp. 579-587.

28. Монгол Улсын Үндэсний Фармакопей (2011). Соёмбо принтинг, Улаанбаатар, х. 509, 531-533, 582, 589, 339, 332, 321, 361, 343.

29. WHO. (1999). Monographs on selected medicinal plants, V1, WHO, Geneva, pp. 50-58.

30. Pharmacopoeia of the People's Republic of China (English edition). (1997). Radix Astragali. Chemical Industry Press, Beijing, VI, pp. 142-143.

31. H. Wagner, B. Sabina. (1996). Plant drug analysis Thin layer chromatography atlas. Springer, pp. 335338.

32. T. Jun. (2004). Determination of total astragalosides in Astragalus by colorimetric method. Journal of Anhui TCM College, 23(5), 37-38.

33. A. Hajisamoh, S. Sosanae, N. Lemeahmad, J. Abu. (2013). Application of solid phase extraction cleanup for the determination of pesticide residues in fresh food items followed by GC-ECD. Research Journal of Pharmaceutical, Biological and Chemical Sciences, 4(2), pp. 22-27.

34. Э. Сугаржав, 3. Оюун. (2016). Цагаалин хунчирын (Astragalus galactites Pall.) өвсний
Монголын Үндэсний Фармакопейн Өгүүлэл 0291-2016.

35. Б. Дагвацэрэн, Г. Наранцэцэг, Л. Хишигжаргал, С. Зина, 3. Оюун, Ө. Батчимэг. (2005). Ургамлын эмийн зохистой хэрэглэгээний гарын авлага. Адмон принт, Улаанбаатар.

36. A.A. Bele, A. Khale. (2011). Standardization of herbal drugs: An overview, International Research Journal of Pharmacy, 2(12), pp. 56-60.

37. WHO. (1999). Monograph on selected medicinal plants: Radix Astragali. WHO, Jeneva, pp. 50-58.

38. European Pharmacopoiea (2010). Astragalus mongholicus root, 7.0, V1, pp. 1060-1061.

39. M. Du, Y-Q. Liu, M-J. Liu, B-J. Xu. (2000). Study on the determination of astragaloside in vanillin phosphoric acid system by spectrophotofluorimetry. Journal of Beijing Medical University, 03.

40. Y-Q. Liu, M. Du, B-J. Xu. (2000). Determination of astragaloside in anisic acid sulfuric acid system by spectrophotofluorimetry. Acta Pharmaceutica Sinica $B, 07$.

\title{
Towards standardization of cultivated two species of astragalus
}

\author{
G. Odontuya ${ }^{1 *}$, R. Odnyam ${ }^{1}$, M. Nomin ${ }^{1}$, Ts. Nomuun ${ }^{1}$, L. Enkhbat ${ }^{2}$, N. Undrakh ${ }^{3}$ \\ ${ }^{1}$ Institute of Chemistry and Chemical Technology, Mongolian Academy of Sciences, Ulaanbaatar 13330, Mongolia. \\ ${ }^{2}$ Astra Root LLC, Delgerkhaan sum, Khentii aimag, Mongolian. \\ ${ }^{3}$ Premium Group LLC, 14241 Ulaanbaatar, Mongolian. \\ *E-mail: odontuyag@mas.ac.mn
}

\begin{abstract}
The cultivation of medicinal plants ensured a stable supply of qualitative raw materials in the drug industry. At the same time, it encourages reservation of important and unique resources of medicinal plants. Pharmacognostic characteristics of roots from Astragalus membranaceus (Fisch.) Bge and Astragalus mongolicus Bge cultivated in the Kherlen Bayan-Ulaan, Khentii aimag in Mongolia have been analyzed. Namely, qualitative characteristics of roots were analyzed according to the methods of Mongolian National Pharmacopoeia and the quantity of active compound saponins was analyzed by the spectrophotometric method, including their permissible limits. According to the experiments, moisture in the two roots was determined as $10.0 \%$. Total ash from the roots was $2.38 \pm 0.05 \%$ in A.membranaceus and $4.18 \pm 0.86 \%$ in A.mongolicus respectively. Acid-insoluble ash was $0.16 \pm 0.04 \%$ and $0.28 \pm 0.07 \%$, water-extracted compounds were $26.83 \pm 0.30 \%$ and $37.51 \pm 1.62 \%$, respectively, which were assured the standard requirements. The quantity of active compound saponins in the root of A.membranaceus was determined at $0.044 \pm 0.009 \%$, while in A.mongolicus $0.028 \pm 0.006 \%$. Hence, the root of A.mongolicus contains more water soluble compounds, especially polysaccharides, while A.membranaceus contains more saponin glycosides.
\end{abstract}

Keywords: Astragalus membranaceus, Astragalus mongolicus, pharmacognostic characteristics, total saponins

(C) The Author(s). 2020 Open Access This article is distributed under the terms of the Creative Commons Attribution 4.0 International License (https://creativecommons.org/licenses/by/4.0/), which permits unrestricted use, distribution, and reproduction in any medium, provided you give appropriate credit to the original author(s) and the source, provide a link to the Creative Commons license, and indicate if changes were made. 